\title{
Studies on the Nutritional Characteristics of some Commercial Wheat Varieties of Dry Land and Wet Land Grown in Sindh Province
}

\author{
Aasia Akbar Panhwar, ${ }^{1,}$, Saghir Ahmed Sheikh${ }^{1}$, Benish Nawaz Mirani ${ }^{1}$, Mahvish Jabeen \\ Channa ${ }^{2}$ and Samia Khanzada ${ }^{1}$
}

${ }^{1}$ Institute of Food Sciences and Technology, Sindh Agriculture University, Tandojam, Pakistan

${ }^{2}$ Department of Food Technology and Nutrition, University of Sindh Jamshoro, Pakistan

\begin{abstract}
The present research was carried out to investigate the nutritional characteristics of some commercial wheat varieties of dry land and wet land grown in Sindh province during 2011-12 at Institute of Food Sciences and Technology, Faculty of Crop Production, Sindh Agriculture University Tandojam. Four irrigated land (Inqulab, TD-1, Sarsabz and kherman) wheat varieties and four dry land (TK-3, Marvi, PK-85, Sassi) wheat varieties were collected from their respective areas and subjected to chemical analysis.

The bio-chemical characteristics of dry land and wet land wheat varieties differed significantly. Chemical analysis indicate that moisture $(13.06 \%)$, protein $(14.83 \%)$, dry gluten $(9.03 \%)$, wet gluten $(35.66 \%)$, gluten index $(73.8 \%)$, starch $(75.83 \%)$ and zeleny $(68.66 \%)$ contents were recorded higher in wet land wheat varieties than those of dry land wheat varieties with moisture $(12.66 \%)$, protein $(11.9 \%)$, dry gluten $(8.2 \%)$, wet gluten $(32.93 \%)$, gluten index $(64.53 \%)$, starch $(68.66 \%)$ and zeleny $(58.33 \%)$. This study reveals that availability of water and environmental factors are directly related with the nutritional characteristics of wheat varieties. This study clarify that wet land wheat varieties are better in the context of nutritional qualities.
\end{abstract}

Keywords: Nutritional characteristics, starch content, zeleny content, protein, gluten index.

\section{INTRODUCTION}

Wheat (Triticum aestivum L.), a member of family poaceae is a leading grain crop of Pakistan. It is staple food for the people of Pakistan [1]. During the year 2010-11, the area under wheat cultivation was 1144.4 thousand hectares with the production of 4287.9 thousand tons. The average yield was $3747 \mathrm{~kg} /$ hectare [2]. Area of wheat crop for the year 2010-11 shows a decrease of $2.53 \%$ over the previous year, due to problems faced by the farmers in disposal of wheat produced.

Wheat occupies a central position in agriculture and economy of Pakistan [3]. Wheat is the most popular food species among the cereals. Besides being a rich source of carbohydrate, wheat contains protein, essential amino acids except lysine, minerals such as phosphorus, magnesium, iron, copper and zinc and thiamine, riboflavin, niacin and vitamin $E$ [4]. In Pakistan about $80 \%$ of the total wheat produced is used for the production of unleavened flat bread locally known as "chapatti" and its culinary variations like "tandoori roti", "naans", "Parathas" and "Poories". However, $20 \%$ of the rest is used for other bakery products such as breads, cookies, cakes and pastries etc [5]. Moreover, it is the cheapest source, providing

*Address correspondence to this author at the Institute of Food Sciences and Technology, Sindh Agriculture University Tandojam, Pakistan;

Tel: +92-3003063464; E-mail: vincaaasia@gmail.com

ISSN: 2223-3806 / E-ISSN: 1927-5951/14 more than $72 \%$ of the calories and proteins to people of the region.

The protein content of wheat varies from $6 \%$ to as much as $22 \%$ depending on the production environment especially soil fertility, water and grain yield. The physical, chemical and nutritional properties of wheat grain are more reliable in evaluation of wheat quality. Hardness, protein content and gluten strength are the basic quality attributes. Protein content is a key quality factor that determine the suitability of wheat for a particular type of product as it affects other factors including mixing tolerance, loaf volume and water absorption capacity. Gluten exhibits plasticity, strength and elasticity which enable wheat flour to form cohesive dough that can expand to accommodate gas and yet resist stretching to bursting points.

It is, therefore, necessary to investigate the biochemical composition of wheat varieties available for food and nutritional purposes in Pakistan, which would provide an opportunity to explore the available wheat varieties for greater excellence in their nutritional quality. The present study was conducted to determine the physiochemical properties and nutritional composition of different wheat varieties.

\section{MATERIALS AND METHODS}

In this study, four varieties of dry wheat TK-3, Marvi, PK-85 and Sassi and four varieties of wet land wheat 
Inqulab, TD-1, Kherman and Sarsabz were selected from popular varieties in Sindh province for determining the nutritional characteristics and their best use for human consumption. The samples of irrigated wheat were collected from Nuclear Institute of Agriculture Tandojam (NIA), Sindh Agriculture University Tandojam, and Agriculture Research Center Tandojam. The samples of dry land wheat were collected from the office of Arid Zone cities namely Johi and Kachoo at Thana Bola Khan. These samples were kept in plastic bags at available moisture content, and were labeled and transported from field to laboratory of Food Sciences and Technology at Sindh Agriculture University Tandojam

All the tests were separately performed according to their nature such as physical analysis and chemical analysis. Laboratory tests were performed in the Cereals Technology Laboratory of Institute of Food Sciences and Technology, Faculty of Crop Production, Sindh Agriculture University Tandojam with the following parameters:

The moisture, Protien, Zeleny and Starch content of wheat grains was determined by Inframatic 9200 Grain Analyzer. It works on the principle of Near Infrared Technology.

\subsection{Gluten Contents on Wet as Well as Dry Weight Basis (Wet + Dry)}

Wet gluten is washed from whole-grain wheat meal or flour by an automatic gluten washing apparatus (Glutomatic) and centrifuged on an especially constructed sieve under standardized conditions. The weight of wet gluten forced through the sieve and the total weight of wet gluten (passed through and remaining on the sieve) are weighed. The total wet gluten is then dried under standardized conditions and weighed. The difference between the weights of total wet gluten and total dry gluten is calculated, which gives the water bound in the wet gluten, referred to as water-binding capacity. Total wet gluten and total dry gluten contents are expressed as percentages of the sample. The gluten content of wheat grains was analyzed by AACC [10] method No. 38-12.

Dry Gluten $\%=\frac{\text { D.G }}{10} * 100$

Wet Gluten $\%=\frac{\text { T.W }}{10} * 100$

Where: D.G denotes to Dry gluten.

\subsection{Gluten Index (\%)}

The gluten index is the ratio of the wet gluten remaining on the sieve (after centrifugation) to the total wet gluten. This method is applicable to wheat meal (ground whole grain) and flour. The gluten index of wheat grains were analyzed by AACC [6] method No. 38-12.

Gluten Index $\%=\frac{\mathrm{R}}{\mathrm{T} . \mathrm{W}} * 100$

Where: $\mathrm{T} . \mathrm{W}=$ Total weight and $\mathrm{R}=$ Remaining.

\section{RESULTS}

\subsection{Moisture Content (\%)}

Moisture content (\%) of dry land and wet land wheat varieties grown in Sindh province is shown in Tables 1 \& 2. The data indicate that maximum mean $13.06 \%$ was recorded in Kherman variety followed by Sarsabz $(12.33 \%)$ wet land wheat varieties. The minimum mean moisture content $10.9 \%$ was recorded in PK-85 variety followed by Marvi (11.03\%) dry land wheat varieties. The moisture content ranged 10.9 to $13.06 \%$ in dry land and wet land wheat varieties respectively.

\subsection{Protein Content (\%)}

Protein content (\%) of dry land and wet land wheat varieties grown in Sindh province is shown in Tables 1 \& 2. The data indicate that maximum mean (14.83\%) was recorded in Sarsabz variety followed by Inqulab $(14.8 \%)$ wet land wheat varieties. The minimum mean protein content $(10.8 \%)$ was recorded in PK-85 variety followed by Sassi $(10.9 \%)$ dry land wheat varieties. The protein content ranged 10.8 to $14.83 \%$ in dry land and wet land wheat varieties respectively.

\subsection{Gluten Contents on Wet as well as Dry Weight Basis (Wet + Dry)}

\subsubsection{Dry Gluten Contents (\%)}

Dry gluten content (\%) of dry land and wet land wheat varieties grown in Sindh province is shown Tables 1 \& 2. The data indicate that maximum mean $(9.03 \%)$ was recorded in TK-3 variety followed by Sassi $(8.46 \%)$ wet land wheat varieties. The minimum mean dry gluten content $(7.53 \%)$ was recorded in Marvi variety followed by Sassi $(8.2 \%)$ dry land wheat varieties. The protein content ranged 7.53 to $9.03 \%$ in dry land and wet land wheat varieties respectively. 
Table 1: Average Biochemical Characteristics of Dry Land Wheat Varieties

\begin{tabular}{|c|c|c|c|c|c|c|}
\hline \multicolumn{7}{|c|}{ Bio-Chemical Characteristics of dry land wheat varieties } \\
\hline \multirow{2}{*}{ Parameters } & \multicolumn{4}{|c|}{ Verities } & \multirow{2}{*}{$\begin{array}{c}\text { F Statistics (P } \\
\text { Value) }\end{array}$} & \multirow{2}{*}{ DF } \\
\hline & PK-85 & Marvi & TK-3 & Sassi & & \\
\hline Moisture content (\%) & $10.9 \pm 0.08 a$ & $11.03 \pm 0.12 \mathrm{a}$ & $11.38 \pm 0.21 b$ & $12.66 \pm 0.30 b$ & $\begin{array}{c}15.874 \\
p=0.001\end{array}$ & 3 \\
\hline Protein content (\%) & $10.8 \pm 0.13 a$ & $11.7 \pm 0.17 \mathrm{~b}$ & $11.9 \pm 0.08 b$ & $10.9 \pm 0.12 a$ & $\begin{array}{c}25.235 \\
p=0.000\end{array}$ & 3 \\
\hline Dry Gluten Content (\%) & $8.06 \pm 0.41$ & $7.53 \pm 0.28$ & $8.16 \pm 0.24$ & $8.2 \pm 0.24$ & $2.033 \mathrm{NS}$ & 3 \\
\hline Wet Gluten Content (\%) & $27.7 \pm 0.37 a$ & $32.93 \pm 0.12 \mathrm{c}$ & $27.66 \pm 0.30 \mathrm{a}$ & $29.23 \pm 0.98 b$ & $\begin{array}{c}40.231 \\
p=0.00\end{array}$ & 3 \\
\hline Gluten Index (\%) & $53.86 \pm 0.80 \mathrm{~b}$ & $64.53 \pm 1.09 c$ & $48.33 \pm 2.28 a$ & $50.8 \pm 1.06 a b$ & $\begin{array}{c}49.629 \\
p=0.00\end{array}$ & 3 \\
\hline Zeleny content (\%) & $55.66 \pm 1.24 a b$ & $57.33 \pm 0.47 \mathrm{bc}$ & $54.66 \pm 0.47 a$ & $58.33 \pm 0.43 c$ & $\begin{array}{c}9.733 \\
p=0.005\end{array}$ & 3 \\
\hline Starch Content (\%) & $68.66 \pm 0.58 d$ & $61.03 \pm 0.15 a$ & $62.73 \pm 0.30 \mathrm{~b}$ & $65.16 \pm 0.31 c$ & $\begin{array}{l}127.372 \\
p=0.00\end{array}$ & 3 \\
\hline
\end{tabular}

Table 2: Average Biochemical Characteristics of Wet Land Wheat Varieties

\begin{tabular}{|c|c|c|c|c|c|c|}
\hline \multicolumn{7}{|c|}{ Bio-Chemical Characteristics of wet land wheat varieties } \\
\hline \multirow{2}{*}{ Parameters } & \multicolumn{4}{|c|}{ Verities } & \multirow{2}{*}{$\begin{array}{c}\text { F Statistics } \\
\text { (P Value) }\end{array}$} & \multirow{2}{*}{ DF } \\
\hline & Inqulab & TD-1 & Kherman & Sarsabz & & \\
\hline Moisture content (\%) & $11.5 \pm 0.40 \mathrm{a}$ & $12.03 \pm 0.12 \mathrm{ab}$ & $13.06 \pm 0.17 \mathrm{c}$ & $12.33 \pm 0.09 b$ & $\begin{array}{c}15.542 \\
p=0.001\end{array}$ & 3 \\
\hline Protein content (\%) & $14.8 \pm 0.13 b$ & $14.06 \pm 0.12 a$ & $13.7 \pm 0.10 \mathrm{a}$ & $14.83 \pm 0.26 b$ & $\begin{array}{c}10.530 \\
p=0.004\end{array}$ & 3 \\
\hline Dry Gluten Content (\%) & $8.33 \pm 0.30 \mathrm{ab}$ & $7.93 \pm 0.12 a$ & $9.03 \pm 0.49$ & $8.46 \pm 0.41 a$ & $\begin{array}{l}3.091 \mathrm{NS} \\
p=0.090\end{array}$ & 3 \\
\hline Wet Gluten Content (\%) & $28.43 \pm 0.23 a$ & $33.73 \pm 0.30 \mathrm{~b}$ & $35.66 \pm 0.41 c$ & $29.06 \pm 0.60 a$ & $\begin{array}{c}145.1 \\
p=0.00\end{array}$ & 3 \\
\hline Gluten Index (\%) & $72.86 \pm 2.10 \mathrm{bc}$ & $69.36 \pm 0.44 a$ & $73.8 \pm 1.23 \mathrm{c}$ & $69.8 \pm 0.43 a b$ & $\begin{array}{c}6.146 \\
p=0.018\end{array}$ & 3 \\
\hline Starch Content (\%) & $69.9 \pm 0.08 a$ & $70.73 \pm 0.17 a$ & $75.83 \pm 0.63 c$ & $71.1 \pm 0.83 b$ & $\begin{array}{c}91.535 \\
p=0.00\end{array}$ & 3 \\
\hline
\end{tabular}

\subsubsection{Wet Gluten Contents (\%)}

Wet gluten content (\%) of dry land and wet land wheat varieties grown in Sindh province is shown in Tables 1 \& 2. The data indicate that maximum mean (35.66\%) was recorded in Kherman variety followed by TD-1 (33.73\%) wet land wheat varieties. The minimum mean content $(27.7 \%)$ was recorded in PK-85 variety followed by TK-3 (27.66\%) dry land wheat varieties. The wet gluten content ranged 27.7 to $35.66 \%$ in dry land and wet land wheat varieties respectively.

\subsection{Gluten Index (\%)}

Gluten Index (\%) of dry land and wet land wheat varieties grown in Sindh province is shown in Tables 1 \& 2. The data indicate that maximum mean $(73.8 \%)$ was recorded in Kherman variety followed by Inqulab $(72.86 \%)$ wet land wheat varieties. The minimum mean gluten index (48.33\%) was recorded in TK-3 variety followed by Sassi (50.8\%) dry land wheat varieties. The gluten index ranged 48.33 to $73.8 \%$ in dry land and wet land wheat varieties respectively. 


\subsection{Zeleny Content (\%)}

Zeleny content (\%) of dry land and wet land wheat varieties grown in Sindh province is shown in Tables 1 \& 2. The data indicate that maximum mean (68.66\%) was recorded in Sarsabz variety followed by Inqulab $(68.33 \%)$ wet land wheat varieties. The minimum mean zeleny content $(54.66 \%)$ was recorded in TK-3 variety followed by PK-85 (55.66\%) dry land wheat varieties. The zeleny content ranged 54.66 to $68.66 \%$ in dry land and wet land wheat varieties respectively.

\subsection{Starch Content (\%)}

Starch content (\%) of dry land and wet land wheat varieties grown in Sindh province is shown in Tables 1 \& 2. The data indicate that maximum mean $75.83 \%$ was recorded in Kherman variety followed by Sarsabz $(71.1 \%)$ wet land wheat varieties. The minimum mean $61.03 \%$ starch content was recorded in Marvi variety followed by TK-3 (62.73\%) dry land wheat varieties. The starch content ranged 61.03 to $75.83 \%$ in dry land and wet land wheat varieties respectively.

\section{DISCUSSION}

The presence of moisture in grain increases the weight of grain which in consequences of storage and milling, decreases the yield of flour reported by Anjum et al. [7]. The results of the present study indicate that moisture content of wet land wheat varieties was higher than those of dry land wheat varieties. This study proved that environmental changes and availability of water are important factor in the estimation of moisture content. The higher moisture content was recorded in wet land wheat varieties, while the lowest was recorded in dry land wheat varieties.

Protein is considered as the most important nutrient for humans and animals. The protein content of wheat grains may vary from $10 \%$ to $18 \%$ of the total dry matter as reported by Sramkova et al. [8]. A wide variation in protein content has been found to be due to different wheat varieties and reflects environmental and genetic factors [9]. The results of present study indicate that protein content of dry land wheat varieties was lower than wet land wheat varieties. The present study further revealed that the nutritional qualities of wet land wheat varieties are remarkable. While, dry land wheat varieties were averaged according to nutritional point of view. In present study protein content ranged between $10.8-14.83 \%$ in dry land and wet land varieties, respectively. Analysis of variance data revealed that wheat plants grown under normally irrigated conditions differed significantly for grain protein from those grown under water limited environment these results are in line with the findings of Ali et al. [10].

The gluten was found to be correlated with protein content of wheat and has significant impact on bread quality [7]. The recovery of wet gluten was (27.07 $35.36 \%)$ and dry gluten was (8.06 - 9.03\%). A considerable variation in gluten content (i.e. wet gluten 23.13 to 38.92$)$ and dry gluten $(8.00-11.60 \%)$ has been reported by Ahmed et al. [12] Khan et al. [21] and Anjum et al. [7]. The results of present study indicated that gluten content (dry+wet) and gluten index of dry land wheat varieties decreased, while much significance is shown by wet land wheat varieties. In present study dry gluten ranged $(7.53-9.03 \%)$, wet gluten ranged $(27.7-35.66 \%)$ and gluten index (48.33 - 73.8\%). The environmental changes and availability of water plays greater role in the nutritional values. Noorka et al. [13] reported that gluten content is mainly a varietal characteristic but high temperature and low relative humidity during the period of grain maturing have a striking harmful effect on the quality of gluten.

It was observed that zeleny content of dry land wheat varieties decreased as compared to wet land wheat varieties. The present study revealed that the nutritional qualities of wet land wheat varieties were remarkable. Ali et al. [10] observed that grain zeleny content on of water deficient plants were significantly lower than those of normally irrigated plants. They also reported that all wheat varieties showed different behavior towards grain zeleny content.

Cereal grains store energy in the form of starch. The amount of starch contained in a wheat grain may vary between $(60-70 \%)$ of the total dry weight of the grain reported by Belderok et al. [14]. The results of present study indicated that starch content of dry land wheat varieties decreased, while starch content of wet land wheat varieties was recorded higher.

\section{CONCLUSION}

The moisture of dry land wheat varieties was recoded lower. This may be due to the insufficient water in dry land. The protein content, gluten (dry+wet), gluten index, zeleny and starch analyzed and recorded the highest in wet land wheat varieties. This indicates that availability of sufficient water play major role in increasing nutritional values of wheat varieties. Wet land varieties are more suitable as compared with dry land because of their softness and high nutritional characteristics. 


\section{ACKNOWLEDGEMENT}

The authors are thankful to growers of dry land areas for dry wheat varieties and wheat Botanist of Research Institute of Sindh Agriculture University Tandojam, for providing the commercial samples of wet land wheat varieties for research purpose.

\section{REFERENCES}

[1] Anonymous. Economic Survey of Pakistan. Economic Advisor's Wing, Finance Division, Govt. of Pakistan, Islamabad 2010.

[2] Government of Pakistan, Statistics Division, Pakistan Bureau of Statistics. Agricultural Statistics of Pakistan 2010-2011.

[3] Shuaib M, Zeb A, Ali W, Ahmad T, Khan I. Characterization of wheat varieties by seed storage protein electrophoresis. Afr J Biotech 2007; 6: 497-500.

[4] Ikhtiar K, Alam Z. Nutritional composition of Pakistani wheat varieties. J Zhejiang Univ Sci 2007; 8(8): 555-559. http://dx.doi.org/10.1631/jzus.2007.B0555

[5] Weegels PL, van de Pijpekamp AM, Graveland A, Hamer RJ, Schofield JD. Depolymerisation and re-polymerization of wheat glutenins during dough processing. I. Relationships between glutenins macro polymer content and quality parameters. J Cereal Sci 1996; 23: 103-111. http://dx.doi.org/10.1006/jcrs.1996.0010
[6] AACC. Approved Methods of the American Association of Cereal Chemist's. The American Association of Cereal Chemist, St. Pauls Minnesota, USA 2000.

[7] Anjum FM, Ahmad S, Rehman S, Butt MS, Bajwa BE. Quality and grading of wheat produced in Faislabad distt. Pak J Food Sci 2003; 13(1-2): 41-44.

[8] Sramkova Z, Fdita G, Sturdik E. Chemical composition and nutritional quality of wheat grain. J Chem Sci 2009; 2(1): 15138.

[9] Khan A, Sharif M, Mahmood A, Khan S, Iqbal M. Assessment of quality parameters in Punjab wheat. Pak $\mathrm{J}$ Food Sci 2002; 12(1-2): 1-5.

[10] Ali F, Iqbal N, Hussain M, Anwar J. Grain quality attributes of wheat lines having differential photosynthetic efficiency under prolonged drought stress. Pak J Bot 2011; 43(5): 2485-2489.

[11] Kent N, Evers AD. Technology of cereals. Perogamon press, oxford 1994.

[12] Ahmed I, Anjum FM, Nazir S, Butt MS, Rafique MA. Milling and cookie backing characteristics of spring wheat varieties of Pakistan. Pak J Food Sci 2002; 12(1-2): 7-13.

[13] Noorka IJ, Rehman S, Haidry JR, Khaliq I, Tabassum S, Mooen G. Effect of water stress on physio-chemical properties of wheat. Pak J Bot 2009; 41(6): 2917-2924.

[14] Belderok B, Mesdag H, Donner DA. Bread-Making Quality of Wheat. Springer, New York 2000. http://dx.doi.org/10.1007/978-94-017-0950-7

\section{DOI: http://dx.doi.org/10.6000/1927-5951.2014.04.04.5}

(C) 2014 Panhwar et al.; Licensee Lifescience Global.

This is an open access article licensed under the terms of the Creative Commons Attribution Non-Commercial License (http://creativecommons.org/licenses/by-nc/3.0/) which permits unrestricted, non-commercial use, distribution and reproduction in any medium, provided the work is properly cited. 